\title{
Biosynthesis, purification, characterization and immobilization of laccase from Lithothelium sp.
}

\author{
Ingrida Radveikiené ${ }^{1}$, \\ Ingrida Pilotaité2, \\ Rimgailė Dainyte் ${ }^{2}$, \\ Regina Vidžiūnaitè ${ }^{1}$ \\ ${ }^{1}$ Institute of Biochemistry \\ Life Sciences Center, \\ Vilnius University, \\ 7 Sauletekio Avenue, \\ 10223 Vilnius, Lithuania \\ ${ }^{2}$ Vilnius Gediminas Technical University, \\ 11 Sauletekio Avenue, \\ 10223 Vilnius, Lithuania
}

\begin{abstract}
Novel fungal laccase isoenzymes (namely L95-1 and L95-2) produced by the Ascomycete Lithothelium sp. isolated from the forest soil were purified. However, only one of them was characterized, because the other isoenzyme lost its activity during purification. Extracellular L95-1 laccase was purified 30-fold using ion-exchange and hydrophobic interaction chromatography, with an overall yield of $88 \%$. The molecular mass of purified L95-1 was estimated to be $85 \mathrm{kDa}$ by SDS-PAGE analysis. L95-1 laccase was stable at temperature $4-22^{\circ} \mathrm{C}$ and $\mathrm{pH}$ 6.0-6.5. The substrate specificity of L95-1 laccase was examined with various compounds. Determined affinity constants $\left(\mathrm{K}_{\mathrm{M}}\right)$ varied in a wide range of 3.7-2020.0 $\mu M$, whereas catalytic efficiency constants $\left(\mathrm{k}_{\text {cat }} / \mathrm{K}_{\mathrm{M}}\right)$ covered a range of $0.008-1.9 \mu M^{-1} \mathrm{~s}^{-1}$. The optimum $\mathrm{pH}$ for most substrates varied in a range from $\mathrm{pH} 5.0$ to 6.0. Sodium azide and fluoride strongly inhibited L95-1 activity, whereas sulphate salts inhibited weakly.

The laccase was immobilized on the $\mathrm{Fe}_{3} \mathrm{O}_{4}$ nanoparticles and characterized. Residual activity remained at $20 \%$ after ten cycles of ABTS oxidation reaction. The immobilized laccase showed higher tolerance to various metal salts. The properties of L95-1 laccase make it potentially useful in the biotechnological applications.
\end{abstract}

Keywords: laccase, biosynthesis, Lithothelium sp., immobilization, magnetic nanoparticles

\section{INTRODUCTION}

Laccases (EC 1.10.3.2, p-diphenol: dioxygen oxidoreductase) are a family of copper-containing oxidases with important applications in bioremediation and other various industrial and biotechnological areas, such as textile, food, biofuel, organic synthesis, bioremediation, paper and pulp, pharmaceutical and cosmetic. Laccase-based biocatalysts fit well with development of industries that are efficient, sustainable and environment-friendly. Laccases were found in bacteria, fungi, insects and plants.

\footnotetext{
* Corresponding author. Email: ingrida.jurkeviciute@gmc.vu.lt
}

Laccases display a wide substrate specificity, and oxidation is coupled with the reduction of an oxygen molecule to water. Although laccases act mainly towards phenolic compounds, such as mono-, di-, poly- and methoxy- phenols, aromatic and aliphatic amines, inorganic/organic metal compound, etc., their action spectrum is wide and the range of oxidizable substrates depends on the specific laccase used [1, 2. Activity of laccase can be inhibited by several agents such as $\mathrm{CN}^{-}, \mathrm{F}^{-}$and fatty acids, which are able to bind to $\mathrm{Cu}^{2+}$ ions thus not proceeding the internal electron transfer, and $\mathrm{Hg}^{2+}$ ions that can induce protein conformations changes [1]. Therefore, newer and novel laccases attract a considerable 
attention due to its promising and valuable multiple applications in the biotechnological industry.

Although laccases are highly active catalysts, they are not always useful for biotechnological applications because of their low stability. This can be increased through the immobilization of the enzyme on solid supports [1], 3]. Enzyme-nanoparticles conjugates designed as industrial biocatalysts are poised to revolutionize many technological processes through ground-breaking new properties and applications. Iron is one of the most abundant metallic elements in living organisms and compared with many other nanoparticles, iron oxide nanoparticles are biologically tolerated. The most common biocompatible magnetic nanomaterials are pure iron oxides, such as maghemite $\left(\gamma-\mathrm{Fe}_{2} \mathrm{O}_{3}\right)$ and mag-

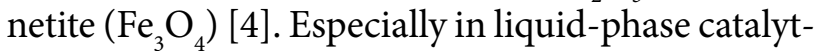
ic reactions, such small and magnetically separable particles may be useful as quasi-homogeneous systems that combine the advantages of high dispersion, high reactivity and easy separation [ 5,6$]$.

Laccases produced by the Ascomycetes, Basidiomycetes, and Deuteromycetes are playing a very important role in many biotechnological applications [7]. Lithothelium is a genus of fungi in the family Pyrenulaceae (lichenized Ascomycete). The Pyrenulaceae family is a widespread distribution [8]. However, information on purified from Lithothelium sp. laccase failed to find. For this reason, we presented a newly isolated laccase from a fungus Lithothelium sp. Laccase was purified, characterized and immobilized on the $\mathrm{Fe}_{3} \mathrm{O}_{4}$ nanoparticles. Laccase characteristic changes after immobilization on the $\mathrm{Fe}_{3} \mathrm{O}_{4}$ nanoparticles were investigated.

\section{EXPERIMENTAL}

\section{Materials}

Materials required for the synthesis of $\mathrm{Fe}_{3} \mathrm{O}_{4}$ nanoparticles: iron (III) chloride, ammonia (CarlRoth $\mathrm{GmbH}$ ) and potassium borohydride (Fluka).

Substrate: 2,2'-azino-bis (3-ethylbenzothiazoline-6-sulfonic acid) diammonium salt (ABTS), promazine hydrochloride (PZ), syringaldazine (SYR) and vanillin (VAN) (Sigma-Aldrich, Switzerland). Methyl syringate (MS) as a product of Lancaster Synthesis was additionally recrystallized from ethanol. 2,6-Dimethoxyphenol (2,6DMP) was obtained from Alfa Aesar, Germany. $N, N$ '-Dimethylamine-4-(4-morpholine)benzene
(AMB) was synthesized according to [9]. 3- $(10 H-$ Phenoxazin-10-yl)propanoic acid (PPA) was synthesized as described in [10]. Catechol (CAT), hydroquinone (HQ) and potassium hexacyanoferrate (11) (FERO) were obtained from Reachim, Russia. Catechin, quercetin, fisetin, gallic, syringic, synapic and chlorogenic acids were obtained from SigmaAldrich (Switzerland), p-coumaric, o-coumaric, $\mathrm{m}$-coumaric, caffeic and ferulic acids were obtained from Fluka (Switzerland).

Metal salts: $\mathrm{AlF}_{3}, \mathrm{KBr}, \mathrm{AlCl}_{3}, \mathrm{CaCl}_{2}, \mathrm{CoCl}_{2}$, $\mathrm{CuCl}_{2}, \mathrm{KCl}, \mathrm{MgCl}_{2}, \mathrm{MnCl}_{2}, \mathrm{NiCl}_{2}, \mathrm{NaOH}, \mathrm{NaCl}$, $\mathrm{KI}, \mathrm{AgNO}_{3}, \mathrm{KNO}_{3}, \mathrm{Co}\left(\mathrm{NO}_{3}\right)_{2}, \mathrm{CoSO}_{4}, \mathrm{CuSO}_{4}$, $\mathrm{Cu}\left(\mathrm{CH}_{3} \mathrm{COO}\right)_{2}$ and $\mathrm{CH}_{3} \mathrm{COONa}$ were obtained from Reachim, Russia; $\mathrm{NaF}$ were obtained from Merck, Germany; $\mathrm{Li}_{2} \mathrm{SO}_{4}, \mathrm{MgSO}_{4}, \mathrm{MnSO}_{4}, \mathrm{Na}_{2} \mathrm{SO}_{4}$, $\mathrm{ZnSO}_{4}, \mathrm{Hg}\left(\mathrm{CH}_{3} \mathrm{COO}\right)_{2}, \mathrm{Zn}\left(\mathrm{CH}_{3} \mathrm{COO}\right)_{2}$ and $\mathrm{NaN}_{3}$ were obtained from Sigma-Aldrich, Switzerland.

The solutions of the investigated substrates were prepared by weight and dissolved in triple distilled water (ABTS, FERO, HQ, CAT, vanillin) or ethanol (AMB, MS, CAA, PPA, PZ, DMP, SYR, catechin hydrate, quercetin, fisetin and ferulic, synapic, gallic, syringic, chlorogenic, p-coumaric, o-coumaric and $\mathrm{m}$-coumaric acids). The final ethanol concentration in the reaction mixture did not exceed $1 \%(\mathrm{v} / \mathrm{v})$.

Fungal strain. The mycelia of fungi taken from the forest soil (Lithuania) were diluted in sterile distilled water, the aliquots were spread on agar medium with ABTS $(1 \mathrm{mM})$, and the plates were incubated at $20^{\circ} \mathrm{C}$ for five days. The culture plate was observed for colour change in the media. ABTS was used for screening of Lithothelium sp. for laccase production, and the front and the back morphology of the ABTS screening-green zone were formed. The laccases were screened and purified at the Department of Biochemistry and Molecular Biology of Life Sciences Center of Vilnius University, Lithuania.

\section{Medium and culture conditions}

The strain was kept on agar plates with $2 \%$ malt extract and $0.4 \%$ yeast extract.

The liquid pre-cultures were prepared by adding $1 \mathrm{~cm}^{2}$ of fungal culture from the agar plates to $50 \mathrm{ml}$ of the medium consisting of $(\mathrm{g} / \mathrm{l})$ : malt extract -3.5 , yeast extract $-2.5, \mathrm{MgSO}_{4}-0.5$, glucose - 8.0, $\mathrm{KH}_{2} \mathrm{PO}_{4}-2.0$, pH 5.5-6.0. Pre-cultures were grown for 3 days at $30^{\circ} \mathrm{C}$ with agitation on a rotary shaker. 
The production of extracellular laccase was carried out in the media, consisting of malt extract $-3.5 \mathrm{~g} / \mathrm{l}$, yeast extract $-2.5 \mathrm{~g} / \mathrm{l}, \mathrm{KH}_{2} \mathrm{PO}_{4}-2.0$ $10.0 \mathrm{~g} / \mathrm{l}, \mathrm{MgSO}_{4}-0.5 \mathrm{~g} / \mathrm{l}, \mathrm{CuSO}_{4}-0.2-2.5 \mathrm{mM}$, pH 3.5-6.5.

Erlenmeyer flasks with $200 \mathrm{ml}$ of the medium were inoculated with $8 \mathrm{ml}$ of a liquid fungal suspension and cultivated for 4-5 days on the rotary shaker at $180 \mathrm{rpm}$ and $22-30^{\circ} \mathrm{C}$.

\section{Enzyme assays}

Purification of laccase isoenzymes. Culture flasks were harvested just after the activity of laccase had reached its production peak. Fungal mycelium was removed by centrifugation at $1500 \times \mathrm{g}$ or filtration. The laccase was purified using various chromatography methods.

CM sepharose $650 \mathrm{M}$ (10 ml/l, TojoSoda, Japan) was added to the culture liquid with L95-1 laccase isoenzymes and was stirred for $4-5 \mathrm{~h}$ (or overnight). The sorbent was precipitated, washed with $5 \mathrm{mM}$ potassium phosphate buffer, $\mathrm{pH} 6.0$, poured to the column, and the adsorbed enzyme was eluted with the $0-0.5 \mathrm{M}\left(\mathrm{NH}_{4}\right)_{2} \mathrm{SO}_{4}$ gradient. Fractions with laccase activity were collected, supplemented with $\left(\mathrm{NH}_{4}\right)_{2} \mathrm{SO}_{4}$ up to $2.0 \mathrm{M}$ and applied to the PHE FF (GE Healthcare) column equilibrated with the $5 \mathrm{mM}$ potassium phosphate buffer, $\mathrm{pH}$ 6.0, with $2.0 \mathrm{M}\left(\mathrm{NH}_{4}\right)_{2} \mathrm{SO}_{4}$. Laccase was eluted with the 2.0-0 M ( $\left.\mathrm{NH}_{4}\right)_{2} \mathrm{SO}_{4}$ gradient. Fractions with laccase activity were collected, concentrated and dialyzed against the $2.5 \mathrm{mM}$ potassium phosphate buffer, $\mathrm{pH}$ 6.0. The enzyme with the lowest hydrophobicity (L95-1) was eluted first. L95-2 was eluted at higher $\left(\mathrm{NH}_{4}\right)_{2} \mathrm{SO}_{4}$ concentration. The L95 isoenzymes were purified separately using ion-exchange chromatography. The Source Q15 (GE Healthcare) sorbent was precipitated, washed with the $5 \mathrm{mM}$ potassium phosphate buffer, $\mathrm{pH} 6.0$, poured to the column, and the adsorbed L95-1 isoenzyme was eluted with the $0-0.5 \mathrm{M}\left(\mathrm{NH}_{4}\right)_{2} \mathrm{SO}_{4}$ gradient. The isoenzyme L95-2 was purified analogously. Isoenzyme L95-1 was eluted when the ionic strength was $32 \mathrm{mM}$ and L95-2 isoenzyme $114 \mathrm{mM}$. Both isoenzymes were concentrated and dialyzed against the $5.0 \mathrm{mM}$ potassium phosphate buffer, $\mathrm{pH}$ 6.0, and were stored at $-20^{\circ} \mathrm{C}$.

Laccase activity assay. Activity of laccase during isolation and purification was determined spectrophotometrically using ABTS as the substrate.
$1 \mathrm{ml}$ of the reaction mixture consisted of $0.975 \mathrm{ml}$ $100 \mathrm{mM}$ sodium citrate buffer, $\mathrm{pH} 3.0,20 \mu \mathrm{l} 10 \mathrm{mM}$ ABTS and $5 \mu \mathrm{l}$ of laccase. ABTS oxidation was monitored by the increase of absorbance at $420 \mathrm{~nm}$ $\left(\varepsilon=36000 \mathrm{M}^{-1} \mathrm{~cm}^{-1}\right)$ at $30^{\circ} \mathrm{C}$. One unit of enzyme was defined as an amount of enzyme that oxidized $1 \mu \mathrm{mol}$ of ABTS per min. Protein concentration was determined by the method of Lowry using bovine serum albumin as standard [11].

Determination of molecular mass. The molecular mass of the purified laccase was estimated by SDS-PAGE analysis. Electrophoresis was performed in $14 \%$ polyacrylamide gels by using molecular mass standards $(170,130,100,70,55$, $40,35,25,15,10 \mathrm{kDa}$ ). Protein bands after SDSPAGE were stained with Coomassie blue R-250 and the molecular masses were determined from the calibration graph.

\section{Kinetic measurements and calculations}

Oxidation of the selected substrates was monitored spectrophotometrically by using a computer controlled Nicolet evolution 300 spectrophotometer (Thermo Electron Corporation, USA) in the $50 \mathrm{mM}$ acetate buffer solution, $\mathrm{pH} 5.5$, at $25^{\circ} \mathrm{C}$. The kinetic curves were recorded at the wavelength corresponding to the maximum of absorbance. The concentration of the oxidized substrates was calculated using the molar absorption coefficients: $\varepsilon_{514}=8.9 \mathrm{mM}^{-1} \mathrm{~cm}^{-1}$ for the radical cations of phenothiazine (PZ) and $\varepsilon_{530}=16 \mathrm{mM}^{-1} \mathrm{~cm}^{-1}$ for phenoxazine derivatives (PPA) [12], $\varepsilon_{414}=36 \mathrm{mM}^{-1} \mathrm{~cm}^{-1}$ for ABTS [13], $\varepsilon_{420}=1.02 \mathrm{mM}^{-1} \mathrm{~cm}^{-1}$ for hexacyanoferrate (II) (FERO) [14], $\varepsilon_{530}=65 \mathrm{mM}^{-1} \mathrm{~cm}^{-1}$ for SYR [15], $\varepsilon_{604}=13.1 \mathrm{mM}^{-1} \mathrm{~cm}^{-1}$ for $\mathrm{AMB}$ [16], $\varepsilon_{410}=0.74 \mathrm{mM}^{-1} \mathrm{~cm}^{-1}$ for CAT [17], $\varepsilon_{248}=17.5 \mathrm{mM}^{-1} \mathrm{~cm}^{-1}$ for HQ [18] and $\varepsilon_{468}=49.6 \mathrm{mM}^{-1} \mathrm{~cm}^{-1}$ for DMP [19]. The value of the molar absorption coefficient of the oxidation product of caffeic acid $\left(\varepsilon_{310}=9.5 \mathrm{mM}^{-1} \mathrm{~cm}^{-1}\right)$, chlorogenic acid $\left(\varepsilon_{325}=14.1 \mathrm{mM}^{-1} \mathrm{~cm}^{-1}\right)$, p-coumaric acid $\left(\varepsilon_{285}=13.7 \mathrm{mM}^{-1} \mathrm{~cm}^{-1}\right)$, ferulic acid $\left(\varepsilon_{310}=13.2 \mathrm{mM}^{-1} \mathrm{~cm}^{-1}\right)$, gallicacid $\left(\varepsilon_{310}=2.7 \mathrm{mM}^{-1} \mathrm{~cm}^{-1}\right)$, syringic acid $\left(\varepsilon_{290}=5.6 \mathrm{mM}^{-1} \mathrm{~cm}^{-1}\right), \quad \mathrm{MS}$ $\left(\varepsilon_{280}=9.8 \mathrm{mM}^{-1} \mathrm{~cm}^{-1}\right)$, vanillin $\left(\varepsilon_{350}=1.1 \mathrm{mM}^{-1} \mathrm{~cm}^{-1}\right)$, quercetin $\left(\varepsilon_{370}=15.2 \mathrm{mM}^{-1} \mathrm{~cm}^{-1}\right)$, fisetin $360 \mathrm{~nm}$ $\left(\varepsilon_{360}=15.6 \mathrm{mM}^{-1} \mathrm{~cm}^{-1}\right)$ and catechin hydrate $\left(\varepsilon_{440}=\right.$ $5.6 \mathrm{mM}^{-1} \mathrm{~cm}^{-1}$ ) was determined experimentally.

The initial rate $(\mathrm{V})$ of substrate oxidation was calculated by curve fitting. In the case of exponential 
function $V=k \cdot C_{0}, \mathrm{k}$ is the first order reaction constant and $C_{0}$ is the initial concentration of a substrate. For the linear dependence the initial rate was calculated as a slope. To analyse the dependence of $V$ on the substrate concentration and determine the apparent kinetic parameters $V_{\max }$ and $K_{\mathrm{M}}$ of the reactions, the Michaelis-Menten equation was used. Catalytic constant $\left(k_{\text {cat }}\right)$ was calculated as ratio $V_{\max }$ and the total enzyme concentration ([E]): $k_{\text {cat }}=\mathrm{V}_{\text {max }} /[\mathrm{E}]$, catalytic efficiency constant was calculated as a ratio of $k_{\text {cat }}$ and $K_{\mathrm{M}}$ :

Catalytic efficiency $=k_{\text {cat }} / K_{\mathrm{M}}$.

\section{Effect of $\mathrm{pH}$, temperature and salts}

\section{The $\mathbf{p H}$ and temperature stability}

For determination of $\mathrm{pH}$ storage stability, samples of enzymes were 10-fold diluted with $200 \mathrm{mM}$ potassium phosphate buffers with various $\mathrm{pH}$ and mixed in tubes. The tubes were closed and stored for $24 \mathrm{~h}$ at temperature of 4,22 and $30^{\circ} \mathrm{C}$. After $24 \mathrm{~h}$, the residual activity was determined as described above with $100 \mu \mathrm{M}$ ABTS. The activity measured immediately after mixing equates to $100 \%$.

For determination of the temperature storage stability of the diluted enzyme solution (samples of enzymes were 500-fold diluted with water), the samples of diluted enzymes were mixed in the tubes. The tubes were closed and stored for 1 month at different temperatures. The residual activity was determined as described above with $100 \mu \mathrm{M}$ ABTS. The activity measured immediately after mixing equates to $100 \%$.

The optimum $\mathrm{pH}$ of laccases with different substrates was measured with a spectrophotometer in a $1 \mathrm{~cm}$ quartz cuvette at $25^{\circ} \mathrm{C}$ using the universal $60 \mathrm{mM}$ Britton-Robinson buffer [20] in a pH range from 3.0 to 9.0 and with different substrates. The highest activity was equated to $100 \%$.

The effect of metal salts on activity of laccases was investigated spectrophotometrically using $100 \mu \mathrm{M}$ of ABTS as substrate, $50 \mathrm{mM}$ sodium acetate buffer solution, $\mathrm{pH} 5.5$, and $0.1-100 \mathrm{mM}$ different salts, at $25^{\circ} \mathrm{C}$. The activity of enzyme without added salt was equated to $100 \%$.

\section{Synthesis of $\mathrm{Fe}_{3} \mathrm{O}_{4}$ magnetic nanoparticles}

The magnetic $\mathrm{Fe}_{3} \mathrm{O}_{4}$ nanoparticles were synthesized according to the method described previously [21]. Specifically, $5 \mathrm{~g}$ of $\mathrm{FeCl}_{3} \cdot 6 \mathrm{H}_{2} \mathrm{O}$ was dissolved in $400 \mathrm{ml}$ of deionized water under vigorous stirring at room temperature. Subsequently, $1.43 \mathrm{~g}$ of $\mathrm{KBH}_{4}$ was dissolved in $50 \mathrm{ml}$ of the ammonia (3.5\%) solution and quickly added to the aqueous Fe(III) solution. Soon after the occurrence of reduction reaction (the solution turning black), the temperature of the solution was increased to $100^{\circ} \mathrm{C}$ and was refluxed for $2 \mathrm{~h}$ under vigorous stirring conditions. Then the solution was cooled to room temperature and aged in water for $24 \mathrm{~h}$. The resulting reaction product was separated by applying an external magnetic field and subsequently washed 5 times by deionized water and dried.

\section{Immobilization of $\mathrm{L95-1}$ on the $\mathrm{Fe}_{3} \mathrm{O}_{4}$ nanoparticles}

The immobilization was carried out by physical adsorption. For enzyme adsorption, $10 \mathrm{mg}$ of $\mathrm{Fe}_{3} \mathrm{O}_{4}$ nanoparticles were sonicated and mixed with the enzyme solution (in volume ratio 1:1), and then the mixture was suspended and kept for $10 \mathrm{~min}$ at room temperature. The immobilized L951-1 was separated by a magnetic field. The immobilization yield (IY) was calculated according to the following formula [22]

$$
I Y(\%)=\frac{P}{P_{o}} \cdot 100 \%,
$$

wherein $\mathrm{P}$ was the amount of enzyme immobilized and $P_{0}$ was the amount of initial enzyme.

The effectiveness factor $(\mathrm{EF})$ was calculated according to the following formula [23]:

$$
\text { Effectiveness factor }=\frac{V_{\max (\text { immobilized enzyme })}}{V_{\max (\text { free enzyme })}} .
$$

Reusability of laccase from the magnetic nanoparticles was investigated by separating the $\mathrm{Fe}_{3} \mathrm{O}_{4}$ nanoparticles with adsorbed laccase and resuspending them in double-distilled water (DD) water or buffer solution several times and activity of the enzyme was determined as described above. The procedure was repeated for 10 consecutive cycles.

\section{RESULTS AND DISCUSSION}

\section{Laccase biosynthesis}

Lithothelium sp. fungal produces two laccase isoenzymes under the same conditions. Both laccase isoenzymes were purified, but it was observed that one of the isoenzymes was very unstable and rapidly 
loses enzymatic activity. Therefore, one of the isoenzymes was investigated in the study. The laccase biosynthesis strongly depended on the cultivation media content. Laccase activity growth was observed for 4 days, and the 5th-day activity was reduced.

The maximum activity of laccase was observed after 4 days when the $\mathrm{Cu}^{2+}$ (inducer) concentration was $2-2.5 \mathrm{mM}$ (Table 1). It was observed that the $\mathrm{pH}$ in the culture medium shifts to the alkaline $\mathrm{pH}$ region during cultivation in the presence of an insufficient concentration of potassium phosphate. Therefore, the effect of potassium phosphate in the enzyme biosynthesis has been studied (Table 2). By cultivation of the laccase, the maximum enzymatic activity was obtained when the inducer concentration was $2 \mathrm{mM}$, and, at the same time, the concentration of potassium salts was $28 \mathrm{mM}$ in the cultivation media at $\mathrm{pH} 6.0,22^{\circ} \mathrm{C}$.

\section{Laccase purification}

The purification of laccase isoenzymes was carried out in three stages: ion-exchange (SuperQ 650M sorbent), hydrophobic interaction (Phenyl FF sorbent) and ion-exchange (Source Q15 sorbent) chromatography (results in Table 3).

After the first purification phase using ion-exchange chromatography, the specific enzyme activity increased from 1.5 to $3.9 \mathrm{U} / \mathrm{mg}$, the protein content decreased to $253 \mathrm{mg}$, the purification fold was 2.6 and the yield was $100 \%$. After hydrophobic interaction chromatography, the specific activity of L95-1 isoenzyme was $16 \mathrm{U} / \mathrm{mg}$ and that of

Table 1. The dependence of biosynthesis efficiency on the $\mathrm{Cu}^{2+}$ concentration at different $\mathrm{pH}$ of cultivation media. Conditions: $\mathrm{KH}_{2} \mathrm{PO}_{4}-14.0 \mathrm{mM}, 30.0^{\circ} \mathrm{C}$

\begin{tabular}{|c|c|c|c|c|c|c|c|c|c|c|c|c|}
\hline \multirow[b]{3}{*}{$\mathrm{Cu}^{2+}$} & \multicolumn{4}{|c|}{5.5} & \multicolumn{4}{|c|}{6.0} & \multicolumn{4}{|c|}{6.5} \\
\hline & \multicolumn{2}{|c|}{4 days } & \multicolumn{2}{|c|}{5 days } & \multicolumn{2}{|c|}{4 days } & \multicolumn{2}{|c|}{5 days } & \multicolumn{2}{|c|}{4 days } & \multicolumn{2}{|c|}{5 days } \\
\hline & $A, \mathrm{U} / \mathrm{ml}$ & $\mathbf{p H}^{*}$ & $\mathrm{~A}, \mathrm{U} / \mathrm{ml}$ & $\mathrm{pH}^{*}$ & $\mathrm{~A}, \mathrm{U} / \mathrm{ml}$ & $\mathrm{pH}^{*}$ & $\mathrm{~A}, \mathrm{U} / \mathrm{ml}$ & $\mathrm{pH}^{*}$ & $\mathrm{~A}, \mathrm{U} / \mathrm{ml}$ & $\mathrm{pH}^{*}$ & $\mathrm{~A}, \mathrm{U} / \mathrm{ml}$ & $\mathrm{pH}^{*}$ \\
\hline $0.75 \mathrm{mM}$ & 0.21 & 6.9 & 0.10 & 7.0 & 0.34 & 7.1 & 0.14 & 7.2 & 0.08 & 7.3 & 0.03 & 7.4 \\
\hline $1.0 \mathrm{mM}$ & 0.04 & 6.8 & 0.12 & 7.0 & 0.08 & 6.9 & 0.08 & 7.1 & 0.01 & 7.1 & 0.04 & 7.2 \\
\hline $1.5 \mathrm{mM}$ & 0.20 & 6.7 & 0.11 & 6.9 & 0.06 & 6.9 & 0.07 & 6.7 & 0.08 & 7.3 & 0.05 & 7.2 \\
\hline $2.0 \mathrm{mM}$ & 0.13 & 6.7 & 0.18 & 6.8 & 0.21 & 6.8 & 0.12 & 6.9 & 0.18 & 7.1 & 0.07 & 7.2 \\
\hline $2.5 \mathrm{mM}$ & 0.14 & 6.5 & 0.17 & 6.8 & 0.20 & 6.8 & 0.12 & 7.0 & 0.31 & 7.0 & 0.13 & 7.1 \\
\hline
\end{tabular}

${ }^{*} \mathrm{pH}$ is $\mathrm{pH}$ of cultivation media during biosynthesis.

Table 2. The dependence of biosynthesis efficiency on $\mathrm{Cu}^{2+}$ and $\mathrm{KH}_{2} \mathrm{PO}_{4}$ concentrations. Conditions: $\mathrm{pH}$ of cultivation media $6.0,24.0^{\circ} \mathrm{C}$

\begin{tabular}{|c|c|c|c|c|c|c|c|c|}
\hline \multirow{2}{*}{$\mathrm{KH}_{2} \mathrm{PO}_{4} \mathrm{Cu}^{2+}$} & \multicolumn{2}{|c|}{$0.5 \mathrm{mM}$} & \multicolumn{2}{|c|}{$1.0 \mathrm{mM}$} & \multicolumn{2}{|c|}{$2.0 \mathrm{mM}$} & \multicolumn{2}{|c|}{$2.5 \mathrm{mM}$} \\
\hline & $\mathrm{A}, \mathrm{U} / \mathrm{ml}$ & $\mathbf{p H}^{*}$ & A, U/ml & $\mathrm{pH}^{*}$ & $\mathrm{~A}, \mathrm{U} / \mathrm{ml}$ & $\mathrm{pH}^{*}$ & $\mathrm{~A}, \mathrm{U} / \mathrm{ml}$ & $\mathrm{pH}^{*}$ \\
\hline $14.0 \mathrm{mM}$ & 0.09 & 7.2 & 0.19 & 6.7 & 0.19 & 7.1 & 0.14 & 6.8 \\
\hline $35.0 \mathrm{mM}$ & 0.07 & 6.7 & 0.10 & 6.7 & 0.17 & 6.5 & 0.16 & 6.5 \\
\hline $70.0 \mathrm{mM}$ & 0.03 & 6.5 & 0.05 & 6.4 & 0.07 & 6.4 & 0.08 & 6.3 \\
\hline
\end{tabular}

${ }^{*} \mathrm{pH}$ is $\mathrm{pH}$ of cultivation media during biosynthesis.

Table 3. The purification profile of laccase isoenzymes produced by Lithothelium sp.

\begin{tabular}{|c|c|c|c|c|c|c|c|}
\hline Purification steps & Isoenzyme & $\begin{array}{c}\text { Volume, } \\
\mathrm{ml}\end{array}$ & $\begin{array}{c}\text { Total enzyme } \\
\text { activity, U }\end{array}$ & $\begin{array}{l}\text { Total protein } \\
\text { content, mg }\end{array}$ & $\begin{array}{c}\text { Specific } \\
\text { activity, U/mg }\end{array}$ & $\begin{array}{l}\text { Purification } \\
\text { fold }\end{array}$ & Yield, \% \\
\hline Culture filtrate (crude extract) & \multirow{2}{*}{ L95 } & 2550 & 998 & 688 & 1.5 & 1.0 & 100 \\
\hline Ion-exchange chromatography & & 36 & 995 & 253 & 3.9 & 2.6 & 100 \\
\hline \multirow{2}{*}{$\begin{array}{l}\text { Hydrophobic interaction } \\
\text { chromatography }\end{array}$} & L95-1 & 8 & 888 & 55 & 16 & 11 & 89 \\
\hline & L95-2 & 3 & 108 & 53 & 2 & 1.3 & 11 \\
\hline \multirow{2}{*}{ lon-exchange chromatography } & L95-1 & 5 & 880 & 20 & 44 & 30 & 88 \\
\hline & L95-2 & 3 & 16 & 13 & 1.2 & 0.8 & 1.6 \\
\hline
\end{tabular}


isoenzyme L95-2 was $2 \mathrm{U} / \mathrm{mg}$. The isoenzyme L951 purification fold was 11 and the yield of laccase $89 \%$, while the purification fold of isoenzyme L952 was 1.3 and the yield was only $11 \%$. After the last purification phase, the yield of L95-1 was $88 \%$ and that of L95-2 was $1.6 \%$.

The molecular mass of laccase L95-1 determined by the SDS-PAGE method is $85 \mathrm{kDa}$.

\section{pH and temperature storage stability of laccase}

The storage conditions of laccase (i.e. $\mathrm{pH}$ and temperature) are very important factors effecting the stability of the enzyme activity as they affect the active site of the laccase, thus effecting the binding to amino acids [24]. Therefore, the effect of $\mathrm{pH}$ on enzyme storage stability was also investigated (Fig. 1). In this study, L95-1 laccase was stable in a $\mathrm{pH}$ range from 6.0 to 6.5 when the temperature ranged from 4 to $22^{\circ} \mathrm{C}$. The activity of laccase was almost undetectable at $30^{\circ} \mathrm{C}$ when the $\mathrm{pH}$ was 7.5.

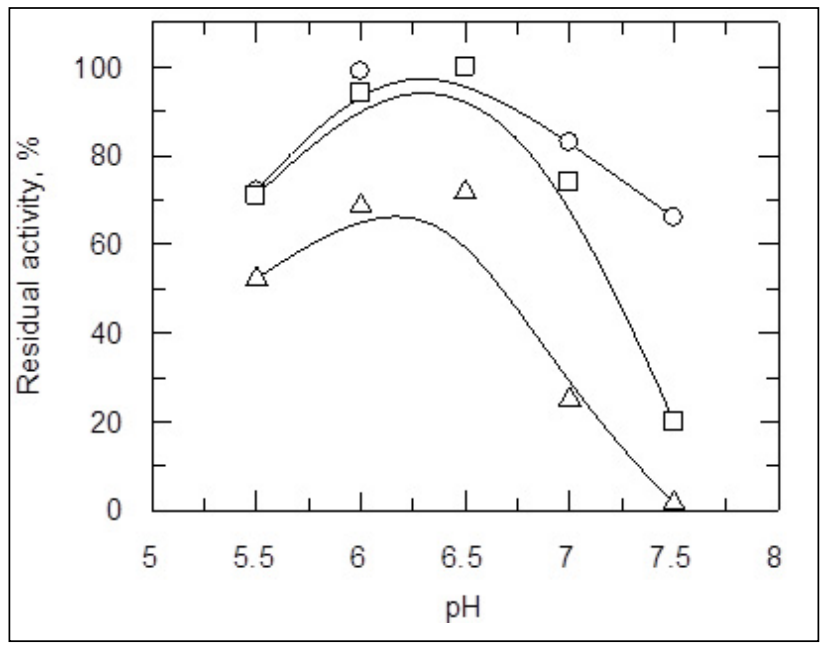

Fig. 1. Analysis of the optimal storage $\mathrm{pH}$ of $\mathrm{L95}-1$ at different temperatures: $4^{\circ} \mathrm{C}(\bigcirc), 22^{\circ} \mathrm{C}(\square), 30^{\circ} \mathrm{C}(\triangle)$. The activity measured immediately after mixing equated to $100 \%$

Also, testing of the storage temperature of pure and diluted until working concentrations L95-1 at different temperatures showed that enzyme remained stable after 12 days at $4^{\circ} \mathrm{C}$ temperature (residual activity up to $80 \%$ ) and the activity of enzyme decreased to $30 \%$ on day 28 (Fig. 2).

The laccase remained stable at $-20^{\circ} \mathrm{C}$ temperature when the enzyme solution was rewarmed and frozen (the residual activity of approximately 90\%), but the activity decreased to $40 \%$ after 28 days.

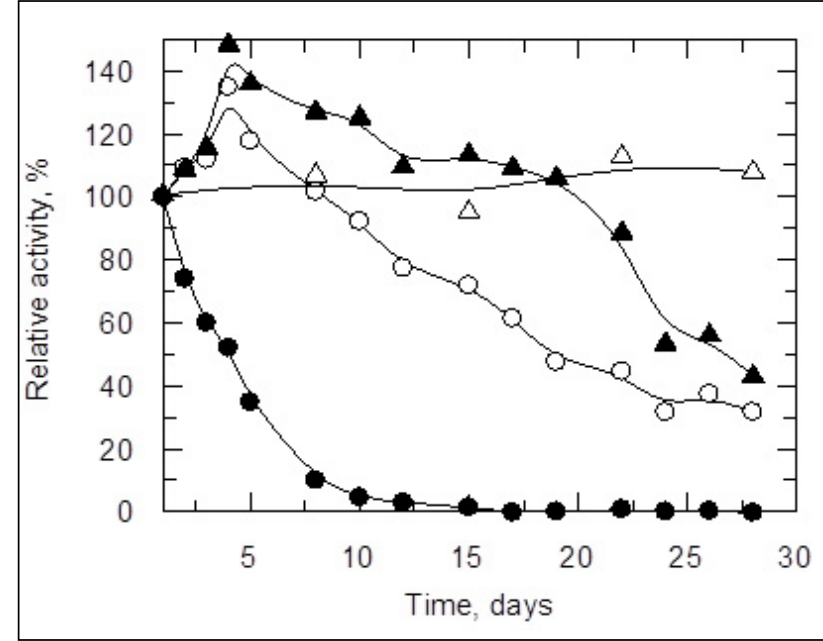

Fig. 2. Diluted L95-1 laccase stability at different temperatures: $4^{\circ} \mathrm{C}$ (O); room temperature $(\mathrm{O}) ;-20^{\circ} \mathrm{C}$, rewarmed just before measurement $(\triangle) ;-20^{\circ} \mathrm{C}$, rewarmed just before measurement, after again refrozen $(\boldsymbol{\Delta})$. Conditions: $50 \mathrm{mM}$ sodium acetate buffer solution $(\mathrm{pH}$



The isoenzyme remained stable (100\% of activity) for 28 days when stored at $-20^{\circ} \mathrm{C}$ and thawed before measurement. Laccase was unstable at room temperature, and its activity was rapidly dropped. After 4 days, the enzyme activity decreased by $50 \%$ and the activity was not detected since the 17 th day.

\section{Kinetic properties and substrate specificity}

The activity of the purified L95-1 was investigated with various phenolic and non-phenolic compounds as substrates, as presented in Table 4 . The results obtained by oxidizing typical laccase substrates showed that the L95-1 isoenzyme was the most affined for SYR, and the minimum value of $K_{\mathrm{M}}(3.7 \mu \mathrm{M})$ was obtained. Analysis of the literature data shows that syringaldazine is the preferred substrate for the laccase from Rigidoporus lignosus, Lentinus edodes, Polyporus pinsitus, Ceriporiopsis subvermispora, Pleurotus ostreatus, Trametes villosa and Trametes pubescens, no matter which fungus is producing the enzyme [25]. Generally, catalytic efficiency $\left(\mathrm{k}_{\mathrm{cat}} /\right.$ $\mathrm{K}_{\mathrm{M}}$ ) is considered an indicator of enzymatic effectivity [26]. The maximum L95-1 catalytic efficiency was determined by oxidizing syringaldazine, and the $\mathrm{k}_{\mathrm{cat}}$ ' $\mathrm{K}_{\mathrm{M}}$ constant value was equal to $1.9 \mu \mathrm{M}^{-1} \mathrm{~s}^{-1}$. The catalytic efficiency of laccase may be indicated as follows: SYR $>$ ABTS $>$ AMB $>$ FERO $>$ CAT $>$ DMP $>$ PPA $>$ HQ $>$ vaniline $>P Z$. Similar results have been observed for recombinant laccase Lac1326, the catalytic efficiency decreased as follows: ABTS $>$ SYR $>$ CAT $>$ DMP [26]. 
Table 4. Kinetic parameters of purified laccase L95-1 for various substrates

\begin{tabular}{|c|c|c|c|}
\hline Substrate & $\mathrm{K}_{\mathrm{M}}, \mu \mathrm{M}$ & $\mathbf{k}_{\mathrm{cat}} \mathrm{s}^{-1}$ & $\mathbf{k}_{\mathrm{cat}} / \mathrm{K}_{\mathrm{M}^{\prime}} \mu \mathrm{M}^{-1} \mathbf{s}^{-1}$ \\
\hline \multicolumn{4}{|c|}{ Typical laccase substrates } \\
\hline ABTS & $14.2 \pm 1.2$ & $13.0 \pm 0.5$ & $0.9 \pm 0.1$ \\
\hline $\mathrm{PZ}$ & $1050.0 \pm 150.0$ & $2.6 \pm 0.3$ & $(2.5 \pm 0.1) \cdot 10^{-3}$ \\
\hline PPA & $148.0 \pm 10.8$ & $17.9 \pm 2.6$ & $(1.2 \pm 1.8) \cdot 10^{-1}$ \\
\hline FERO & $645.0 \pm 10.0$ & $19.0 \pm 1.0$ & $(3.0 \pm 0.1) \cdot 10^{-2}$ \\
\hline SYR & $3.7 \pm 0.3$ & $6.7 \pm 1.0$ & $1.9 \pm 0.3$ \\
\hline AMB & $1200.0 \pm 180.0$ & $44.0 \pm 2.0$ & $(4.0 \pm 1.0) \cdot 10^{-2}$ \\
\hline CAT & $2020.0 \pm 200.0$ & $30.0 \pm 6.0$ & $(1.5 \pm 0.1) \cdot 10^{-2}$ \\
\hline $\mathrm{HQ}$ & $995.0 \pm 105.0$ & $7.6 \pm 1.7$ & $(8.0 \pm 2.0) \cdot 10^{-3}$ \\
\hline DMP & $70.0 \pm 15.0$ & $4.4 \pm 0.5$ & $(6.4 \pm 1.0) \cdot 10^{-2}$ \\
\hline MS & - & - & $(6.4 \pm 2.0) \cdot 10^{-3}$ \\
\hline Vanilline & - & - & $(2.5 \pm 0.2) \cdot 10^{-3}$ \\
\hline \multicolumn{4}{|c|}{ Hydroxycinnamic acids } \\
\hline Caffeic acid & $55.1 \pm 6.2$ & $5.9 \pm 0.2$ & $(11.0 \pm 0.2) \cdot 10^{-2}$ \\
\hline Chlorogenic acid & $130.0 \pm 25$ & $11.0 \pm 2.0$ & $(9.0 \pm 2.0) \cdot 10^{-2}$ \\
\hline p-Coumaric acid & $1330.0 \pm 300.0$ & $0.9 \pm 0.2$ & $(1.0 \pm 0.1) \cdot 10^{-3}$ \\
\hline o-Coumaric acid & - & - & - \\
\hline m-Coumaric acid & - & - & - \\
\hline Ferulic acid & $23.0 \pm 4.0$ & $7.0 \pm 0.03$ & $0.3 \pm 0.05$ \\
\hline Sinapic acid & $24.0 \pm 6.0$ & $20.1 \pm 0.5$ & $0.9 \pm 0.03$ \\
\hline \multicolumn{4}{|c|}{ Hydroxybenzoic acids } \\
\hline Gallic acid & $590.0 \pm 50.0$ & $22.0 \pm 2.0$ & $(4.0 \pm 0.2) \cdot 10^{-2}$ \\
\hline Syringic acid & $45.0 \pm 5.0$ & $5.0 \pm 0.5$ & $0.1 \pm 0.02$ \\
\hline \multicolumn{4}{|c|}{ Flavonoids } \\
\hline Quercetine & $9.5 \pm 0.5$ & $11.0 \pm 0.5$ & $1.1 \pm 0.1$ \\
\hline Fisetine & $13.5 \pm 2.0$ & $8.0 \pm 0.5$ & $0.6 \pm 0.05$ \\
\hline Catechin hydrate & $120.0 \pm 20.0$ & $2.3 \pm 0.4$ & $(2.0 \pm 0.4) \cdot 10^{-2}$ \\
\hline
\end{tabular}

Ferulic and synapic acids were observed to be most efficiently oxidized by L95-1 laccase $(0.3$ and $0.9 \mu \mathrm{M}^{-1} \mathrm{~s}^{-1}$, respectively), comparing the $k_{\text {cat }} / K_{\mathrm{M}}$ values determined by oxidation of hydroxycinnamic acids. The minimum catalytic efficiency of L95-1 was determined by oxidizing p-coumaric acid $\left(1 \cdot 10^{-3} \mu \mathrm{M}^{-1} \mathrm{~s}^{-1}\right)$. Moreover, L95-1 did not oxidize other coumaric acid isomers.

The highest affinity of L95-1 among hydroxybenzoic acids was determined for syringic acid. Among flavonoids, the highest affinity was determined for quercetin $(9.5 \mu \mathrm{M})$.

\section{The effect of $\mathrm{pH}$ on the rate of oxidation reaction} The optimum $\mathrm{pH}$ of the oxidation reactions of substrates catalyzed by laccases depends not only on the substrate but also on the nature of the enzyme.
Because of a difference in the redox potential of type I copper of laccase and the substrate, the optimum $\mathrm{pH}$ of enzyme activity varies with the substrate used [27]. The effect of $\mathrm{pH}$ on the activity of laccase with different substrates (A-B are typical laccase substrates, $B$ is hydroxycinnamic acid and $\mathrm{D}$ is hydroxybenzoic acid) was presented in Fig. 3 . The bell-shaped dependence of the enzyme activity on the buffer solution $\mathrm{pH}$ was observed mostly during the oxidztion of typical laccase substrates (AMB, DMP, SYR). But the dependence was sigmoidal when laccase oxidizes ABTS. The optimum $\mathrm{pH}$ obtained for L95-1 laccase was 6.0 with AMB and DMP as substrates. During laccase catalyzed DMP oxidation only slight changes in the activity were observed in the $\mathrm{pH}$ interval from 4.0 to 5.0 , whereas the activity decreased with both increasing and 


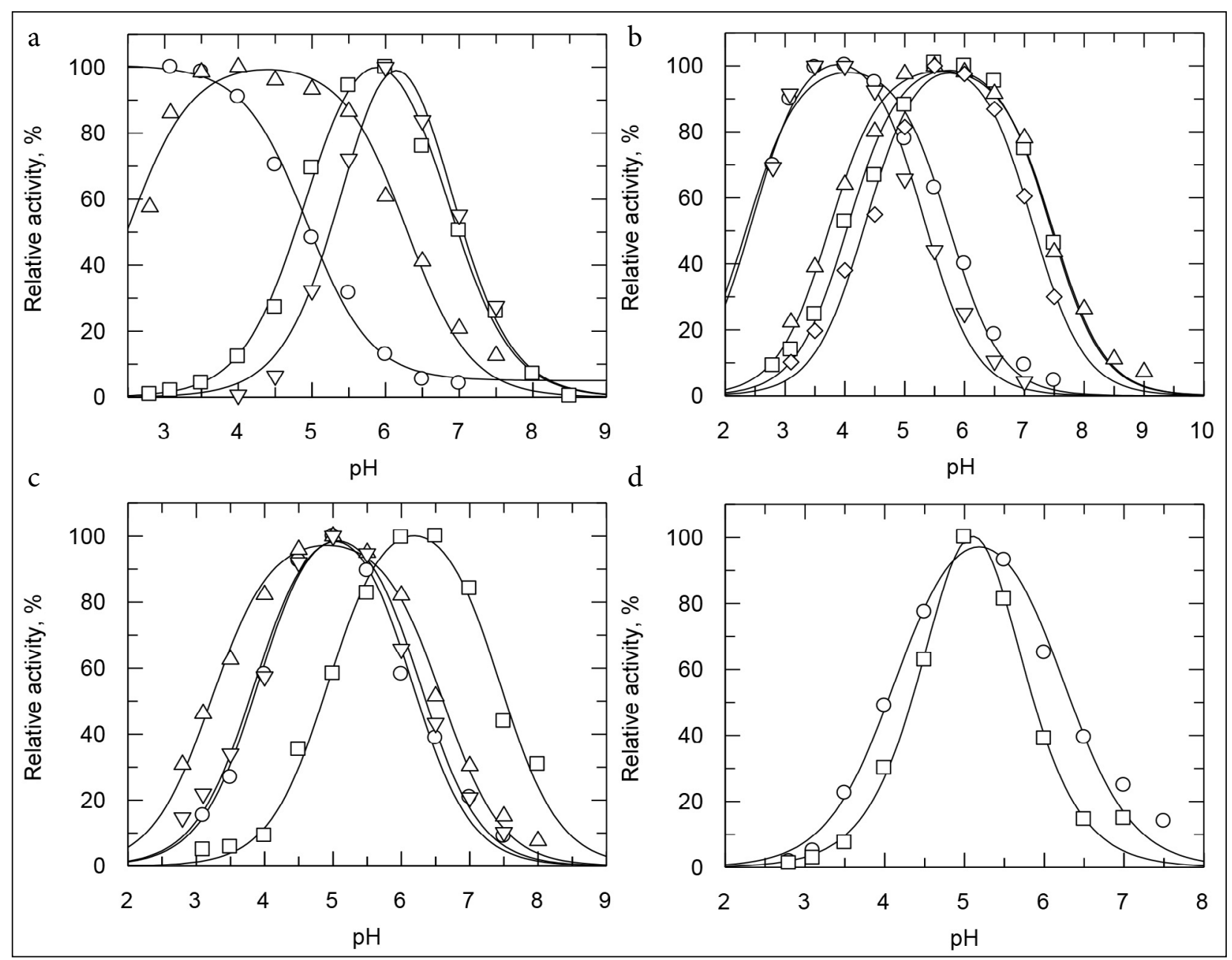

Fig. 3. Effect of different pH on the L95-1 activity using standard (a-b), hydroxycinnamic acid (c) and hydroxybenzoic acid (d) substrates. a: ABTS $(\bigcirc)$, AMB $(\square)$, DMP $(\triangle)$, SYR $(\nabla)$; b: PPA $(\bigcirc), \operatorname{PZ}(\square), \operatorname{CAT}(\triangle)$, FERO $(\nabla)$, HQ $(\diamond)$; c: caffeic acid $(\bigcirc)$, p-coumaric acid $(\square)$, sinapic acid $(\triangle)$, ferulic acid $(\nabla)$; d: gallic acid $(\bigcirc)$, syringic acid $(\square)$. Conditions: $60 \mathrm{mM}$ Britton-Robinson buffer, $25^{\circ} \mathrm{C}$. The highest activity was equated to $100 \%$

decreasing the $\mathrm{pH}$ of the buffer solution. The analysis of literature data showed that the $\mathrm{pH}$ dependencies of phenolic compounds such as DMP and SYR were predominantly bell-shaped with activity peak values in a $\mathrm{pH}$ range from 4.0 to 7.0 [28].

The optimum $\mathrm{pH}$ of the oxidation of ABTS catalyzed by L95-1 was at $\mathrm{pH}$ 3.0. Laccases from T. versicolor, T. hirsute, T. villosa, P. ostreatus also have their optimum $\mathrm{pH}$ around $\mathrm{pH} 3.0$ and show no significant activity above $\mathrm{pH}$ 6.5-8.0 when substrate ABTS was used [29].

\section{Effects of metal ions}

Metal ions are known to bind to the enzyme and alter its activity by stabilization or destabilization of the protein conformation [30]. The effects of some metal salts on the activity of L95-1 were shown in Table 5 and Fig. 4 .
Table 5. Influence of various metal salts on the activity of L95-1 laccase

\begin{tabular}{ccc}
\hline Metal salts & Concentrations, $\mathrm{mM}$ & Residual activity, $\%$ \\
\hline $\mathrm{NaN}_{3}$ & 0.1 & $10 \pm 1$ \\
\hline $\mathrm{Hg}\left(\mathrm{CH}_{3} \mathrm{COO}\right)_{2}$ & 1 & $10 \pm 1$ \\
\hline $\mathrm{AgNO}_{3}$ & 1 & $20 \pm 2$ \\
\hline $\mathrm{NaF}$ & 1 & $30 \pm 2$ \\
\hline $\mathrm{AlF}_{3}$ & 1 & $95 \pm 2$ \\
\hline $\mathrm{Kl}$ & 10 & $23 \pm 1$ \\
\hline $\mathrm{Cdl}$ & 10 & $25 \pm 2$ \\
\hline $\mathrm{Cu}\left(\mathrm{CH}_{3} \mathrm{COO}\right)_{2}$ & 10 & $55 \pm 5$ \\
\hline $\mathrm{CaCl}_{2}$ & 20 & $10 \pm 3$ \\
\hline $\mathrm{CoCl}_{2}$ & 20 & $20 \pm 1$ \\
\hline $\mathrm{MgCl}_{2}$ & 20 & $40 \pm 2$ \\
\hline $\mathrm{KCl}$ & 20 & $40 \pm 2$ \\
\hline $\mathrm{AlCl}_{3}$ & 20 & $30 \pm 1$ \\
\hline
\end{tabular}


Table 5. (Continued)

\begin{tabular}{ccc}
\hline Metal salts & Concentrations, mM & Residual activity, $\%$ \\
\hline $\mathrm{NiCl}_{2}$ & 20 & $35 \pm 2$ \\
\hline $\mathrm{CuCl}$ & 20 & $50 \pm 1$ \\
\hline $\mathrm{MnCl}_{2}$ & 20 & $55 \pm 5$ \\
\hline $\mathrm{NaCl}$ & 20 & $60 \pm 5$ \\
\hline $\mathrm{Zn}\left(\mathrm{CH}_{3} \mathrm{COO}\right)_{2}$ & 20 & $60 \pm 4$ \\
\hline $\mathrm{ZnSO}_{4}$ & 20 & $60 \pm 2$ \\
\hline $\mathrm{CuSO}$ & 20 & $80 \pm 2$ \\
\hline $\mathrm{Co}\left(\mathrm{NO}_{3}\right)_{2}$ & 20 & $80 \pm 3$ \\
\hline $\mathrm{KNO}_{3}$ & 20 & $85 \pm 5$ \\
\hline $\mathrm{CoSO}_{4}$ & 20 & $97 \pm 4$ \\
\hline $\mathrm{Li}_{2} \mathrm{SO}_{4}$ & 20 & $95 \pm 5$ \\
\hline $\mathrm{MnSO}_{4}$ & 20 & $100 \pm 4$ \\
\hline $\mathrm{MgSO}_{4}$ & 20 & $100 \pm 8$ \\
\hline $\mathrm{KBr}_{3}$ & 100 & $45 \pm 2$ \\
\hline $\mathrm{CH}_{3} \mathrm{COONa}_{20}$ & 100 & $80 \pm 5$ \\
\hline $\mathrm{Na}_{2} \mathrm{SO}_{4}$ & 100 & $98 \pm 4$ \\
\hline
\end{tabular}

Salts with $\mathrm{Cu}^{2+}$ ions weakly reduced the activity of L95-1 laccase. Similar results were observed for Cerrena sp. laccase [31]. The weakly effect of $\mathrm{Cu}^{2+}$ on the activity of laccase can be explained due to the filling of type I copper-binding site by $\mathrm{Cu}^{2+}$ ions [32]. Sodium azide and fluoride inhibited the activity of L95-1, the residual activity was 10 and 30\%, respectively (when $0.1 \mathrm{mM} \mathrm{NaN}_{3}$ or $1 \mathrm{mM} \mathrm{NaF}$ were used).

The inhibition by $\mathrm{NaN}_{3}$ and $\mathrm{NaF}$ can be explained by the binding of azide or fluoride to the trinuclear copper centre, that affects internal electron transfer, which ultimately affects the overall oxidation process catalyzed by laccase [33, 27]. Also $\mathrm{Cl}^{-}$and $\mathrm{I}^{-}$strongly inhibited the activity of laccase L95-1. The inhibition of laccase activity by sulphate salts was so slight and cation dependent.

\section{Immobilization of laccase}

Laccase L95-1 was immobilized by applying adsorption. Adsorption is a fast and usual method of

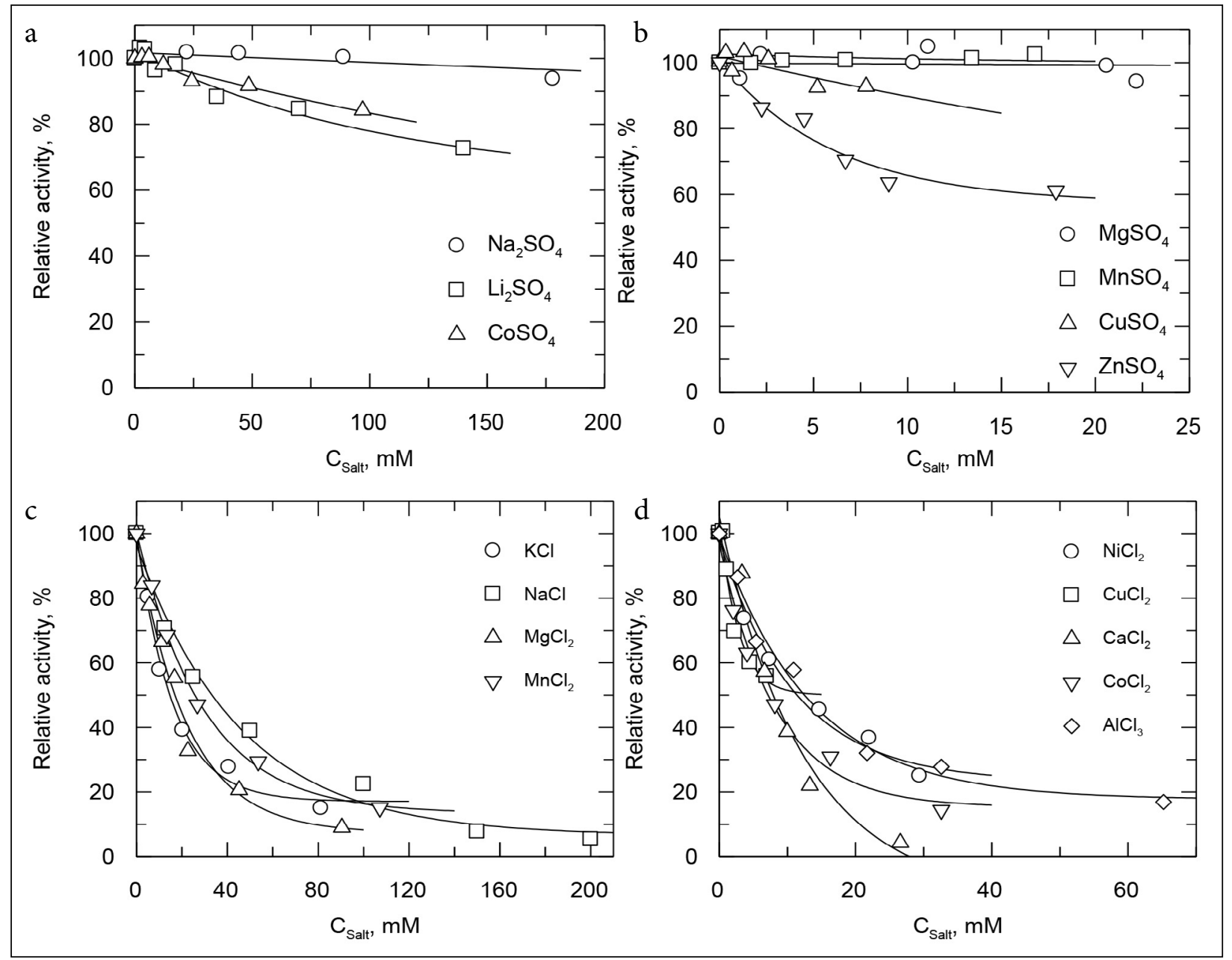

Fig. 4. Effect of different sulphate and chloride salts on the activity of L95-1. Conditions: $50 \mathrm{mM}$ acetate buffer solution, pH 5.5 , at $25^{\circ} \mathrm{C}$, $100 \mu \mathrm{M}$ of ABTS as substrate. The activity of enzyme without salt was equated to $100 \%$ 
immobilization, which practically does not modify the natural conformation of an enzyme [34]. The synthesized magnetic nanoparticles used in this study were characterized previously [21]. Immobilization of laccase on the $\mathrm{Fe}_{3} \mathrm{O}_{4}$ nanoparticles can be affected by various factors. In the present study, the enzyme concentration which was used for immobilization and adsorption time was optimized.

The effect of laccase concentration used for immobilization (interval from 7 to $22 \mathrm{nM}$ ) on the relative activity of immobilized L95-1 was investigated and shown in Fig. 5. The immobilized laccase L95-1 showed the maximum activity at the enzyme concentration of $10.8 \mathrm{nM}$, whereas the enzyme activity in the supernatant at this enzyme concentration was low.



Fig. 5. The effect of L95-1 concentration used for immobilization on the immobilized laccase activity ( $\square$ ) and laccase activity in supernatant $(\mathbb{Q})$. Conditions: activity was determined in $50 \mathrm{mM}$ acetate buffer solution, $\mathrm{pH} 5.5$, at $25^{\circ} \mathrm{C}, 100 \mu \mathrm{M}$ of $\mathrm{ABTS}$ as substrate

Adsorption time is also a key factor during the enzyme immobilization process [35]. The effect of adsorption time on the immobilized laccase L951 enzymatic activity was shown in Fig. 6. The relationship of adsorption time to laccase activity displayed a dynamic equilibrium. The relative activity increased when the adsorption rate was greater than the desorption rate and decreased when the adsorption rate was slower than the desorption rate.

As can be seen in Fig. 6, the relative activity decreased after each incubation cycle. The adsorption time of 10 min was chosen for further immobilization. The activity of immobilized laccase decreased with increasing the incubation time. After $24 \mathrm{~h}$

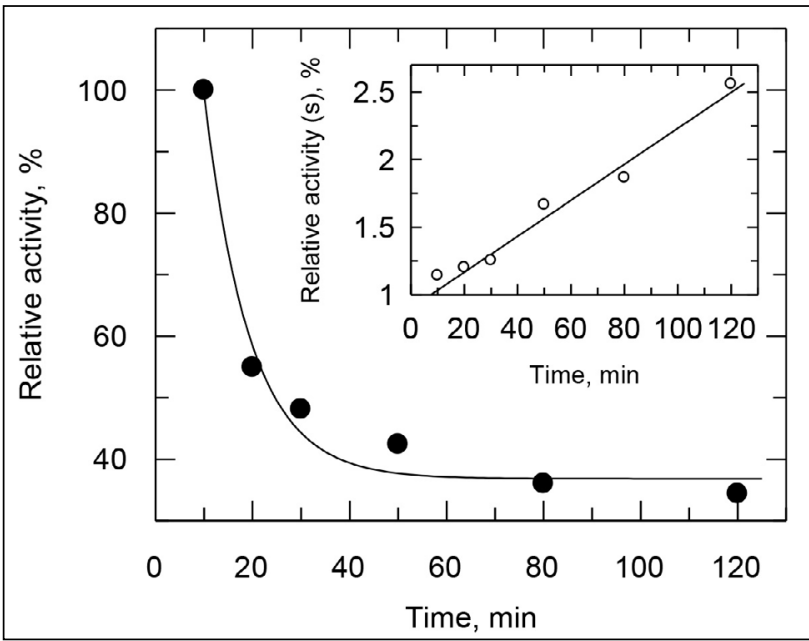

Fig. 6. The effect of adsorption time on the immobilized laccase ( $)$ and laccase in supernatant $(\bigcirc)$ activity. Conditions: activity was determined in $50 \mathrm{mM}$ acetate buffer solution, $\mathrm{pH} 5.5$, at $25^{\circ} \mathrm{C}, 100 \mu \mathrm{M}$ of ABTS as substrate

activity of immobilized enzyme remained similar to the activity after $1 \mathrm{~h}$. The activity of enzyme increased in the supernatant with increasing the time of incubation.

According to the calculations, about $40 \%$ of native L95-1 was adsorbed on the $\mathrm{Fe}_{3} \mathrm{O}_{4}$ nanoparticles.

\section{Reusability of the immobilized laccase}

The reusability of immobilized laccase was studied. 10 consecutive cycles of substrate oxidation/magnetic separation/redispersion were used for reusability determination (Fig. 7). After 5 cycles of reuse,

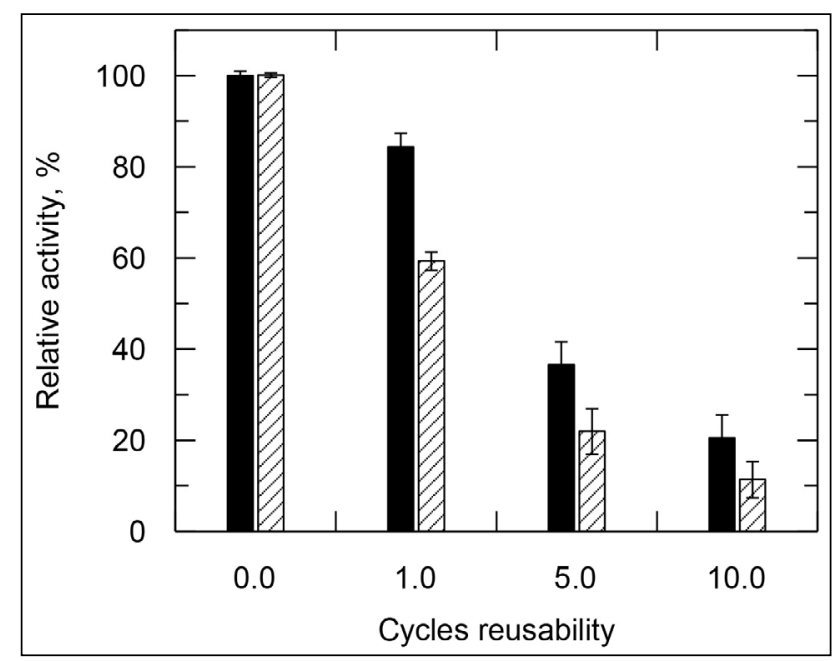

Fig. 7. Cycles of the reusability of $L 95-1$ laccase in $50 \mathrm{mM}$ sodium acetate buffer solution, pH $5.5(\mathbf{\square})$, and in DD water $(\mathbb{\mathbb { Q }})$. Conditions: activity was determined in $50 \mathrm{mM}$ acetate buffer solution, $\mathrm{pH} 5.5$, at $25^{\circ} \mathrm{C}, 100 \mu \mathrm{M}$ of ABTS as substrate 
60 and $80 \%$ of the initial laccase activity were lost in the buffer solution and DD water, respectively. The enzymatic activity of immobilized laccase represented approximately $20 \%$ of the initial enzyme activity after 10 consecutive reutilization cycles in the buffer solution and DD water. The decrease was attributed to the stress suffered by the laccase after each magnetic separation because of the formation of compact aggregates. The amount of desorbed laccase depends on the re-suspending media and the number of repeated procedures [36].

\section{Kinetic parameter study}

The apparent Michaelis-Menten constants $\left(\mathrm{K}_{\mathrm{M}}\right)$ for both the free and immobilized L95-1 were determined and compared (Table 6). The higher $\mathrm{K}_{\mathrm{M}}$ value for the immobilized laccase indicates its lower affinity for the substrate compared to that of the free laccase. The higher catalytic efficiency constant was determined for the free laccase compared to the immobilized one ( 0.87 and $0.32 \mu \mathrm{M}^{-1} \mathrm{~s}^{-1}$, respectively). The effectiveness factor for the immobilized laccase was determined and was equal to 1.45 . The value of effectiveness factor above 1 shows that the immobilization does not affect the diffusion of the substrate and the product. Generally, enzymes lose some of their catalytic power when they are immobilized as the apparent $\mathrm{K}_{\mathrm{M}}$ of immobilized enzymes is higher, and $V_{\text {mar }}$ values are lower than those for free enzymes [37]. The observed changes of laccase L95-1 in the catalytic properties upon immobilization are the apparent $K_{\mathrm{M}}$ and $V_{\text {max }}$ values increase, whereas $\mathrm{k}_{\text {cat }}$ and $k_{\text {cat }} / K_{\mathrm{M}}$ decrease.

A possible application of the immobilized laccase could be oxidation of the phenolic compounds, such as 2,6-DMP, in wastewater. The structure of such chromogenic phenolic laccase substrates is similar to that of certain target pollutants (such as industrial chemicals, nonylphenol and bisphenol A) [38, 39]. Therefore, we studied how the immobilized L95-1 laccase on magnetic nanoparticles was able to oxidize 2,6-DMP. The kinetic param- eters were presented in Table 6. The apparent $\mathrm{K}_{\mathrm{M}}$ of the immobilized laccase for DMP oxidation was relatively low compared to $\mathrm{K}_{\mathrm{M}}$ values of the free L951-1. The maximum reaction rates of free and immobilized laccase were similar, 0.009 and $0.008 \mu \mathrm{M} / \mathrm{s}$, respectively. Whereas the values of catalytic $\left(k_{\text {cat }}\right)$ and catalytic efficiency $\left(k_{\text {cat }} / K_{\mathrm{M}}\right)$ constants decreased after laccase immobilization.

\section{Effect of $\mathbf{p H}$}

The $\mathrm{pH}$ profile of native laccase L95-1 activity upon the oxidation of ABTS was sigmoidal, whereas the $\mathrm{pH}$ profile of this laccase immobilized on magnetic nanoparticles was bell-shaped, as shown in Fig. 8 .

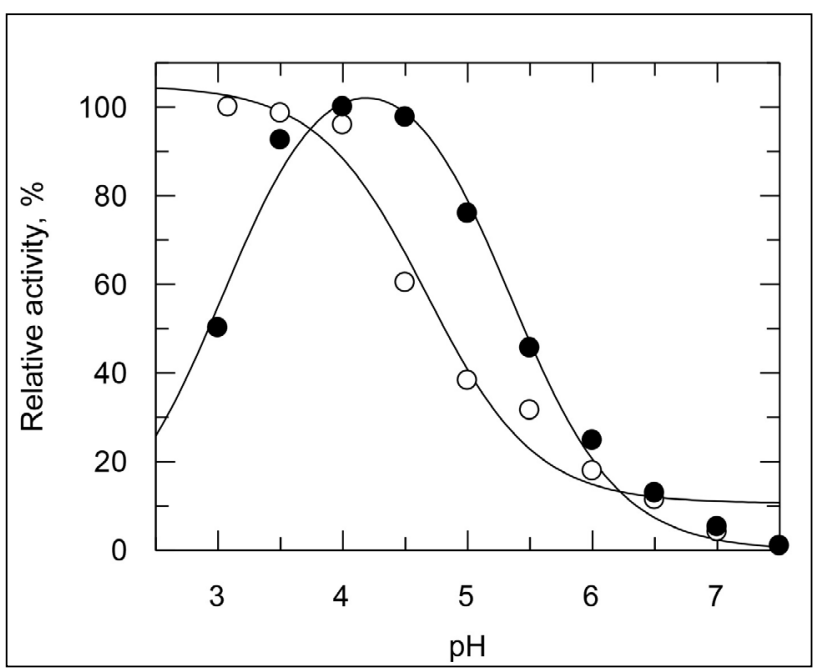

Fig. 8. The effect of buffer solution $\mathrm{pH}$ on the free $(\bigcirc)$ and immobilized (O) laccase activity. Conditions: $60 \mathrm{mM}$ Britton-Robinson buffer, $25^{\circ} \mathrm{C}$. The highest activity was equated to $100 \%$

The optimum $\mathrm{pH}$ of immobilized laccase activity was found to be 4.0-4.5 and the optimum $\mathrm{pH}$ of free laccase was 3.0. The immobilized laccase L95-1 action was significantly better than that of the free laccase in a $\mathrm{pH}$ range from 4.5 to 6.0.

Hence, this could be due to the protective effect provided by the laccase fixation on the nanoparti-

Table 6. Kinetic constants of the ABTS and DMP oxidation catalysed by free and immobilized L95-1 laccase

\begin{tabular}{c|c|c|c|c|c}
\hline Substrate & Enzyme & $\boldsymbol{K}_{\mathrm{M}^{\prime}} \boldsymbol{\mu M}$ & $\boldsymbol{V}_{\max } \boldsymbol{\mu M} / \mathbf{s}$ & $\boldsymbol{k}_{\mathrm{cat}} \mathbf{s}^{-1}$ & $\boldsymbol{k}_{\text {cat }} / \boldsymbol{K}_{\mathrm{M}^{\prime}}, \boldsymbol{M M}^{-1} \mathbf{s}^{-1}$ \\
\hline \multirow{2}{*}{ ABTS } & Free L95-1 & $14.9 \pm 1.6$ & $0.029 \pm 0.001$ & $13.0 \pm 0.46$ & $0.87 \pm 0.09$ \\
\cline { 2 - 6 } & Immobilized L95-1 & $27.9 \pm 3.7$ & $0.042 \pm 0.0015$ & $8.9 \pm 0.3$ & $0.32 \pm 0.04$ \\
\hline \multirow{2}{*}{ DMP } & Free L95-1 & $70.0 \pm 15.0$ & $0.009 \pm 0.0005$ & $4.4 \pm 0.5$ & $0.064 \pm 0.01$ \\
\cline { 2 - 6 } & Immobilized L95-1 & $35.3+7.4$ & $0.008 \pm 0.0005$ & $1.7 \pm 0.1$ & $0.046 \pm 0.01$ \\
\hline
\end{tabular}


cles during adsorption at room temperature. A shift of the optimum $\mathrm{pH}$ after laccase immobilization was also reported in a number of previous studies [40, 41].

\section{Effect of metal salts}

The effect of metal salts on the activity of immobilized laccase was studied and compared with the results obtained with free laccase (Fig. 9).



Fig. 9. The effect of metal salts on the free $(O)$ and immobilized $(O$ activity of laccase L95-1. Conditions: $50 \mathrm{mM}$ acetate buffer solution, $\mathrm{pH} 5.5$, at $25^{\circ} \mathrm{C}, 100 \mu \mathrm{M}$ of $\mathrm{ABTS}$ as substrate
The used salts inhibited the activity of the immobilized laccase L95-1 less than that of the free enzyme. The relative activity of immobilized laccase was higher about $15-20 \%$ with $\mathrm{NaN}_{3}$, $20 \%$ with $\mathrm{NaF}$ and $10 \%$ with $\mathrm{CaCl}_{2}$ compared to free.

\section{CONCLUSIONS}

In summary, laccase was purified and its properties were determined. The best substrate for purified laccase was syringaldazine. The bell-shaped dependence of the enzyme activity on the buffer solution $\mathrm{pH}$ was observed mostly during the oxidation of typical laccase substrates (AMB, DMP, SYR). But the dependence was sigmoidal when laccase oxidizes ABTS.

Copper salts weakly reduced activity, but azide, fluoride, chloride and iodide salts strongly inhibited the activity of laccase L95-1. The inhibition of laccase activity by sulphate salts was so slight and cation dependent.

Laccase was successfully immobilized on the $\mathrm{Fe}_{3} \mathrm{O}_{4}$ nanoparticles. According to the calculations about $40 \%$ of native L95-1 was adsorbed on the nanoparticles. The properties of immobilized laccase such as $\mathrm{pH}$ stability and resistance to various metal salts were significantly improved compared with those of the free enzyme. The results showed that the immobilized laccase L95-1 on magnetic nanoparticles have the potential of oxidation phenolic compounds.

\section{ACKNOWLEDGEMENTS}

We thank Liucija Marcinkevičiene from the Life Sciences Center of Vilnius University for her assistance with the biosynthesis and purification of laccase from Lithothelium sp. and for comments that greatly improved the manuscript.

Received 21 April 2020 Accepted 2 June 2020

\section{References}

1. A. Salis, M. Pisano, M. Monduzzi, V. Solinas, E. Sanjust, J. Mol. Catal. B Enzym., 58, 175 (2009).

2. J. Yang, W. Li, T. Bun Ng, X. Deng, J. Lin, X. Ye, Front. Microbiol., 8, 1 (2017).

3. O. Saoudi, N. Ghaouar, Int. J. Biol. Macromol., 128, 681 (2019). 
4. C. Iriarte-mesa, S. Díaz-castañón, D. G. Abradelo, Colloids Surf. B Biointerfaces, 181, 470 (2019).

5. J. Lin, Q. Lai, Y. Liu, S. Chen, X. Le, X. Zhou, Int. J. Biol. Macromol., 102, 144 (2017).

6. Y. Liu, Z. Zeng, G. Zeng, et al., Bioresour. Technol., 115, 21 (2012).

7. G. Janusz, A. Pawlik, U. Swiderska-Burek, et al., Int. J. Mol. Sci., 21(966), 1 (2020).

8. A. Aptroot, Lichenologist, 38(6), 541 (2006).

9. J. Kulys, T. Buch-Rasmussen, K. Bechgard, et al., J. Mol. Catal., 91(3), 407 (1994).

10. L. Ramirez-Cavazos, C. H. Junghanns, N. OrnelasSoto, et al., J. Mol. Catal. B Enzym., 108, 32 (2014).

11. H. W. Huang, G. Zopperllaro, T. Sakurai, J. Biol. Chem., 274(46), 32718 (1991).

12. J. Kulys, K. Krikstopaitis, A. Ziemys, J. Biol. Inorg. Chem., 5, 333 (2000).

13. L. Marcinkevičienè, R. Vidžiūnaitè, D. Tauraitė, et al., Chemija, 24, 48 (2013).

14. K. A. Schellenberg, L. Hellerman, J. Biol. Chem., 231, 547 (1958).

15. J. M. Harkin, J. R. Obst, Experientia, 29, 381 (1973).

16. J. Kulys, L. Tetianec, A. Ziemys, J. Inorg. Biochem., 100(10), 1614 (2006).

17. S. Shleev, O. Nikitina, A. Christenson, et al., Bioorg. Chem., 35, 35 (2007).

18. R. C. Minussi, M. Miranda, J. Silva, et al., African J. Biotechnol., 6, 1248 (2010).

19. G. Eibes, M. T. Moreira, G. Feijoo, A. J. Daugulis, J. M. Lema, Chemosphere, 66, 1744 (2007).

20. A. M. Michałowska-Kaczmarczyk, T. Michałowski, J. Solution Chem., 44, 1256 (2015).

21. J. Gružauskaitė, J. Jasinskaitè, R. Meškys, et al., Catal. Commun., 135, 1 (2020).

22. Z. Lv, Q. Yu, Z. Wang, R. Liu, J. Microbiol. Biotechnol., 29(6), 913 (2019).

23. M. L. Shuler, F. Kargi, Bioprocess Engineering, 2nd edn., Prentice-Hall, Upper Saddle River (2002).

24. X. Xu, L. Feng, Z. Han, S. Luo, A. Wu, J. Xie, J. Microbiol. Biotechnol., 26(9), 1570 (2016).

25. N. N. Pozdnyakova, J. Rodakiewicz-Nowak, O. V. Turkovskaya, J. Haber, J. Mol. Catal B Enzym., 41, 8 (2006).

26. Q. Yang, M. Zhang, M. Zhang, et al., Front. Microbiol., 9, 1 (2018).

27. S. Sondhi, P. Sharma, S. Saini, N. Puri, N. Gupta, PLoS One, 9, 1 (2014).

28. P. Babu, R. Pinnamaneni, S. Koona, Univers. J. Environ. Res. Technol., 2, 1 (2012).

29. S. Scheiblbrandner, E. Breslmayr, F. Csarman, et al., Sci. Rep., 7(13688), 1(2017).

30. K. K. Sharma, B. Shrivastava, V. R. B. Sastry, N. Sehgal, R. C. Kuhad, Sci. Rep., 3(1299), 1 (2013).

31. X. Xu, X. Huang, D. Liu, J. Lin, X. Ye, J. Yang, J. Taiwan. Inst. Chem. Eng., 84, 1 (2018).

32. Shraddha, R. Shekher, S. Sehgal, M. Kamthania, A. Kumar, Enzyme Res., 2011, 1 (2011).
33. M. M. Atalla, H. K. Zeinab, R. H. Eman, A. Y. Amani, A. A. El, A. Abeer, Saudi J. Biol. Sci., 20, 373 (2013).

34. G. Castro, A. Gonzalez, I. Tzompantzi, F. ViniegraGonzalez, Rev. Mex. Ing. Quim., 12, 241 (2013).

35. D. Liu, J. Chen, Y. Shi, Anal. Chim. Acta, 1006, 90 (2018).

36. C. Iriarte-Mesa, S. Diaz-Castanon, D. G. Abradelo, Colloids Surf. B, 181, 470 (2019).

37. A. Blandino, M. Macías, D. Cantero, Process Biochem., 36, 601 (2001).

38. R. Hochstrat, T. Wintgens, P. Corvini, Immobilized Biocatalysts for Bioremediation of Groundwater and Wastewater, IWA Publishing Alliance House, London (2015).

39. P. Singh, C. Bindi, G. Arunika, 3 Biotech., 7(5), 323 (2017).

40. G. Bayramoglu, B. Karagoz, M. Y. Arica, J. Ind. Eng. Chem., 60, 407 (2018).

41. W. Bankeeree, S. Prasongsuk, T. Imai, P. Lotrakul, H. Punnapayak, BioResources, 11, 6984 (2016).

Ingrida Radveikienè, Ingrida Pilotaitè, Rimgailè Dainytè, Regina Vidžiūnaitė

\section{LAKAZĖS IŠ LITHOTHELIUM SP. BIOSINTEZE், GRYNINIMAS, CHARAKTERIZAVIMAS IR IMOBILIZACIJA}

Santrauka

Nauji grybinès lakazès izofermentai (pavadinti L95-1 ir L95-2) produkuojami Askomicetų Lithothelium sp., išskirti iš miško dirvožemio ir išgryninti. Tačiau tik vienas iš jų charakterizuotas, nes kitas izofermentas gryninimo metu prarado savo aktyvumą. Ekstraląstelinè L95-1 lakazè buvo išgryninta 30 kartų naudojant jonų mainų ir hidrofobinès sąveikos chromatografiją, bendra išeiga 88 \%. Nustatyta, kad išgrynintos L95-1 molekulinè masė yra $85 \mathrm{kDa}$, taikant SDS-PAGE analizę. L95-1 lakazè buvo stabili esant $4-22{ }^{\circ} \mathrm{C}$ temperatūrai ir pH 6,0-6,5. L95-1 lakazès substratinis specifiškumas ištirtas su įvairiais junginiais. Nustatytos giminingumo konstantos $\left(K_{\mathrm{M}}\right)$ svyravo plačiame 3,7-2020 $\mu \mathrm{M}$ diapazone, o katalitinio efektyvumo konstantos $\left(k_{\mathrm{cat}} / K_{\mathrm{M}}\right)$ varijavo $0,008-1,9 \mu M^{-1} \mathrm{~s}^{-1}$ intervale. Optimalus $\mathrm{pH}$ daugumai substratų svyravo nuo 5,0 iki 6,0. Natrio azidas ir fluoridas stipriai slopino L95-1 aktyvumą, o sulfato druskos - silpnai.

Lakazè buvo imobilizuota ant $\mathrm{Fe}_{3} \mathrm{O}_{4}$ nanodalelių ir charakterizuota. Nustatyta, kad išlieka $20 \%$ pradinio fermentinio aktyvumo po dešimties reakcijų ciklų oksiduojant ABTS. Imobilizuota lakazè pasižymi didesne tolerancija ịvairioms metalų druskoms. L95-1 lakazės savybės rodo potencialias galimybes panaudoti ją biotechnologiniuose procesuose. 